\title{
Financial Performance and Social Responsibility-The Case of Islamic Banks: A Theoretical and Empirical Study
}

\author{
Tarek Chenini ${ }^{1}$, Ahlem Boubker ${ }^{2}$, Sawssen Nafti ${ }^{1} \&$ Mosbah Lafi ${ }^{2}$ \\ 1 Faculty of Economics and Management of Sousse Laboratory, University of Sousse, Tunisia \\ ${ }^{2}$ Higher Institute of Management of Gabès, University of Gabès, Tunisia \\ Correspondence: Tarek Chenini, Faculty of Economics and Management of Sousse Laboratory, University of \\ Sousse, Tunisia. E-mail: chenini.tarekk@gmail.com
}

Received: June 25, 2021

Accepted: August 10, 2021

Online Published: August 15, 2021

doi:10.5539/ijef.v13n9p94

URL: https://doi.org/10.5539/ijef.v13n9p94

\begin{abstract}
This article is intended to evaluate the level of disclosure of corporate social responsibility (CSR) in Islamic banks and examine the relationship between the Return on Assets (ROA) and the Return on Equity (ROE) performance indices in relation to the disclosure of the Islamic banks' corporate social responsibility. In reality, an empirical study was performed over a six-year period from 2009 to 2014, in which the CSR shows that Islamic banks are engaged in a great variety of social activities, both as private or public banks. In fact, empirical research has also found that there is a negative relationship between the corporate social responsibility of Islamic banks and the financial results of the ROA an ROE measures.
\end{abstract}

Keywords: Islamic banks' social responsibility, financial performance, Returns on Assets (ROA), Return on Equity (ROE) measures

\section{Introduction}

Islamic banking is built on the notion of profit and loss sharing in theory, but unlike traditional banks, it does not lend money for interest. In today's Islamic banking, however, two opposing legal doctrines have emerged. In a globally competitive banking sector, progressive Islamic scholars say that there is no need to develop products currently given by traditional banks. Islamic banks, on the other hand, should make the bare minimum of changes to these traditional goods in order to achieve Shari'a compliance. Furthermore, Islamic banks adhere to the moral economy concept, which is defined for legal, religious, or secular purposes, and encourages the integration of social and environmental objectives into their investment plans (Belal et al., 2014). In fact, according to Ahmad (2000), Islamic banks should strike a balance between giving acceptable returns to their owners and depositors while remaining mindful of their social responsibilities and promises to their diverse stakeholders.

As a result, we selected two ex-post-calculated success assessment indicators of this type: Return on Equity (ROE) and Return on Assets (ROA). Moreover, among the researchers that has looked into the elements that influence the production of Islamic banks. M. Kabir, Hassan, and colleagues (2000) investigated how the bank's features and the overall financial climate affect the bank's performance. In fact, between 1994 and 2001, the authors looked at the performance metrics of Islamic banks all around the world. The obtained results showed that corporate social responsibility of an Islamic bank specifies the relationship between the company and the bank's social standing.

In fact, in an empirical study to explain and investigate the theoretical hypotheses, Arshad et al. (2012), Mallin et al. (2014) reported a positive relationship between financial performance and CSR of Islamic banks whereas Barnett and Salomon (2006) found a negative one. Therefore, our objective in this work is to examine the relationship not only between the social responsibility of Islamic banks and financial results but also between banks themselves. In fact, we attempt to find answers to the following questions.

Is there a link between Islamic banks' corporate social responsibility and their financial performance?

We will examine the many hypotheses and research studies that have sought to investigate and clarify the relationship between corporate social responsibility and financial efficiency in our case study. Furthermore, we will apply the regression techniques to experimentally investigate this link for a sample of Islamic banks in 
various countries.

In reality, this article adds to the growing body of CSR literature on Islamic banks. First, while there have been some empirical research studies on the relationship between CSR and financial success in Islamic banks, as far as we know, this is the first study to empirically deal with Islamic banks using major CSR aspects, such as donations or "Waqf,".

For this reason, in what follows, we will present the structure of this document. In fact, the literature review and the hypothesis creation are covered in section 2 . Then, the procedures for collecting the sample and analyzing it are then detailed in sections 3 and 4. After that, in section 5, the obtained results are described and the observations presented, and in section 6, the observations are summarized and concluded.

On the other hand, defining CSR is challenging due to the numerous definitions and interpretations that have been offered over time. In fact, since the 16th century, when the phrase was first coined in French, the CSR perception has evolved as well. To understand the principle of corporate social responsibility (CSR), we have first to distinguish between the idea and the present movement that has sparked this idea. On the other hand, CSR is a long-standing notion that dates back to the 19th century, when corporate paternalism was prevalent in the developed countries. In fact, it was initially stated in the United States during WWII, with the first contemporary "business ethics" emphasizing the leader's moral personal responsibility. Moreover, in the 1970s, a second movement called the "utilitarian approach" emerged, claiming that responsible behavior might improve a company's economic efficiency however, a third new trend based on the notion of sustainability, emphasizes the importance of businesses' contribution to long-term success.

\section{Literature Review}

\subsection{Previous Research on CSR Disclosure}

In reality, several studies have defined corporate social responsibility. For example, McWilliams and Siegel (2001) defined it as "the carrying out of any ativity not required by the legislation of the countries in which these enterprises conduct their businesses for the benefit of the society rather than for their own benefits." On the other hand, corporate social responsibility was described by Lea (2002) as "all the types of corporations and other organizations that go beyond the legal requirements to control their impact on both the environment and the society." This could involve, for example, how businesses connect with their employees, suppliers, consumers, and the communities in which they operate.

For his part, Hopkins (1999) noted that within the idea of CSR, business stakeholders are addressed in an ethical or socially responsible way. Furthermore, because these stakeholders exist both inside and outside a firm, their human development can be attained by acting in a socially responsible way both inside and outside the organization.

According to Zahid and Pervaiz (2004), Islamic enterprises' focus is on technological and economic solutions, justifies the lack of CSR in these organizations. Moreover, they demonstrated that the reliance on external processes, such as supervision and reward systems, leads to individual win-loss alternatives which, from the standpoint of strategic planning, represent the symbol of the secular economy. On the other hand, corporate social responsibility-driven innovation (CSRBI) relies on win-win solutions to foster a CSR culture that emphasizes collaboration and open space between organizational and non-organizational stakeholders.

In an Islamic context, and in a much larger sense, CSR is viewed as encompassing the importance of the fear of God (Taqwa) in all situations in which everyone in the organization must perform their duty as servants and vice-recruits (Dusuki, 2008). As a result, someone who values Taqwa recognizes that his or her purpose in life is to govern and build the world in accordance with Sha'riah principles and ideals. In fact, the Sha'riah is an ethical framework the ideals of which encompass all the aspects of life, including people's personal, social, political, economic, and intellectual attitudes, which are inextricably linked to Islam's essential principles, values, and aims (Ziauddin, 2003).

\subsection{Some Research Studies on Corporate Social Responsibility in the Islamic Banking Sector}

Moreover, a number of researches have looked into the extent of CSR practiced by the IBs in the Islamic financial institutions (IFIs). In this vein, Maali et al. (2006) looked into the scope of social activities revealed by Islamic banks. They also connected the disclosure of these activities to the social practices that Islamic banks should embrace, especially those that are relevant to the society. In fact, they found that banks that adhered to mandated concerns, like paying Zakat and implementing the requirements of the Accounting and Auditing Organization for Islamic Financial Institution (AAOIFI) provided greater disclosures than banks that did not. Furthermore, Islamic banks favor disclosures that help to promote a positive Islamic image, such as 
philanthropic actions. On the other hand, Haniffa and Hudaib (2007) looked into the disclosure of information deemed crucial in Islamic business ethics. In fact, the authors created an ideal ethical benchmark based on the five features that differentiate the Islamic banks from their conventional counterparts. For their part, Abdul Rahman et al. (2010) investigated an Islamic bank's CSR disclosure in Malaysia. Over the course of the 14-year investigation, they discovered that the number and quality of IB CSR disclosures improved.

For their part, Belal et al. (2014), used a longitudinal research with two major exceptions. First, they showed the disclosure tendencies of a Bangladeshi Islamic bank during a 28 -year period, spanning three unique eras of the Islamic banking industry: before 1990, 1990-2001, and after 2001. On the other hand, Hassan and Harahap (2010) conducted a similar study on Haniffa and Hudaib (2007), concentrating on the disclosure of social activities in seven Islamic banks' annual reports. In fact, they found a considerable discrepancy in expectations in all but one of the seven banks, implying that IB CSR issues are not the primary concern of most Islamic banks. As for Aribi and Gao (2012) they studied the CSR narrative statements from 21 Islamic financial institutions (IFIs) operating in the Gulf region. They discovered that the IFIs' key CSR disclosures were contained in the SSB reports, whereas the annual reports on other Islamic core disclosures, such as Zakat, interest-free loans, and charity donations, featured less information.

Table 1. The main research studies about the CSR disclosure in Islamic banks

\begin{tabular}{|c|c|c|c|c|}
\hline Authors & Year & $\begin{array}{l}\text { Type of establishment and } \\
\text { countries in the sample }\end{array}$ & $\begin{array}{c}\text { Size of the } \\
\text { sample and year }\end{array}$ & Measuring the CSR \\
\hline Maali et al. & $(2006)$ & Islamic banks in the world & $29(2000)$ & Index of disclosure containing 30 elements. \\
\hline Haniffa and Hudaib & $(2007)$ & $\begin{array}{l}\text { The banks } \\
\text { The Islamic Gulf States }\end{array}$ & $7(2002-2004)$ & Ethical Identity Index containing 78 goods \\
\hline Abdul Rahman et al. & $(2010)$ & Islamic banks in Malaysia & $1(1992-2005)$ & Adaptation of the Maali index \\
\hline Hassan and Harahap & (2010) & $\begin{array}{l}\text { The Islamic banks in Bahrain } \\
\text { and in Bangladesh }\end{array}$ & 7 (2006) & Adaptation of the Haniffa and Hudaib index \\
\hline Farook et al. & (2011) & Islamic banks in the world. & 47 (2007) & Adaptation of the Maali index \\
\hline Aribi and Gao & (2012) & $\begin{array}{l}\text { Islamic banks in the Gulf } \\
\text { countries }\end{array}$ & $21(2004)$ & Narrative reports \\
\hline Belal et al. & (2014) & Islamic banks in Bangladesh & $1(1983-2010)$ & $\begin{array}{l}\text { Index of disclosure containing } 149 \text { items through } \\
16 \text { Islamic banks listed in different categories }\end{array}$ \\
\hline
\end{tabular}

\subsection{Islamic Banks' Corporate Social Responsibility (CSRIB) and Financial Performance (FP)}

In fact, the financial success of banks is evaluated using a range of criteria, including those that use the company's accounting data and those that are based on the market prices.

Moreover, various scholars, among whom, Waddock and Graves, (1997), have pointed out that the existence of many variables in the relationship between social and financial performance causes neutrality. As a result, it is thought that there is no direct linear relationship between IBs' CSR and financial performance. In fact, according to this assumption, social performance is not correlated with the financial one, which implies that corporate social responsibility does not affect the financial results (Soana 2011, p. 135).

For their part, Mallin et al. (2014) conducted a similar study that looked at the relationship between CSR and the financial performance of Islamic banks in various countries between 2010 and 2011. In fact, their research found a strong link between financial success and CSR among the investigated Islamic institutions. On the other hand, in Malaysian Islamic banks, the relationship between CSR and financial success has been measured using four dimensions, such as the environment, the market, the community, and the workplace. The regression was further tested using the Return on Assets (ROA) and the Return on Equity (ROE). As a result, when customized and combined, the ROA, the ROE, and financial performance have dealt with a favorable relationship. However, only a few research studies have looked into the relationship between CSR and Islamic banks' performance.

Moreover, several empirical investigations have proven the detrimental association between IBs' CSR and financial performance. However the opponents of CSR, such as Barnett and Salomon (2006), argue that being socially active through philanthropic organizations, supporting and encouraging employees' welfare and reducing the environmental damage can be costly and requires administrative costs.

On the other hand, Preston and O'Bannon's (1997) theory, which claims that financial performance negatively affects corporate social responsibility, supports the negative association between Islamic banks' CSR and 
financial performance. However, proponents of this theory claim that by pursuing socially responsible efforts, businesses are jeopardizing their fundamental goal.

However, recent proponents argue that funds allocated to social programs or initiatives should be diverted and spent on businesses' efficiency or returned to the shareholders (Perrini et al., 2011, p. 69). In fact, these authors contend that companies should not be responsible for social issues that should be addressed by governments or the non-profit sector. Those who say that IB CSR should not be integrated into business agendas and operations also note to the potential detrimental impacts of excessive role diversification, believing that managers with numerous purposes are managers without goals (Jensen, 2001). As a result, including CSR efforts into the bank will act as a deterrent to banks competing for survival.

According to Hassan et al. (2010); Arshad et al. (2012); Mallin et al. (2014), examining the relationship between the CSR and the financial performance of Islamic banks in the Gulf Cooperation Council (GCC) region for the period 2000/2014, assumes that there is a positive relationship between these two variables and the risks from the Islamic banks' CSR financial performance.

As for Arshad et al. (2012), they attempted to study the impact of CSR on the performance of Islamic banks. In fact, in their study, which was conducted on a sample of Malaysian Islamic banks between 2008 and 2010, they concluded that the reporting of social commitment is positively related to corporate performance as measured by the ROA and the ROE. Therefore, our study is part of this study as it seeks to examine the relationship between the functioning of Islamic banks and the level of organizational commitment. Based on this review, we get the following two ideas:

H1: There is a positive relationship between return on assets (ROA) and social responsibility of Islamic banks.

$\mathrm{H} 2$ : There is a positive relationship between return on equity (ROE) and social responsibility of Islamic banks.

The two hypotheses are empirically examined to check if hypotheses $\mathrm{H} 1$ and $\mathrm{H} 2$ give the same sign with CSR in the IBs.

\section{The Sample and the Data}

To test these hypotheses and answer the problem, we will continue with the retrospective models using specific data on them. Therefore, in our study, we used a sample of 15 Islamic banks for the period between 2009 and 2014. Moreover, the data was collected from the annual reports of Islamic banks, Bankscope database and banks' websites.

\subsection{The Dependent Variable}

CSR of IBs = donations (sadaqa) or waqf / profit before tax

Islamic banks' social responsibility is measured using their CSR

The major CSR details about IBs were taken from the SSB report with little disclosure in the annual reports of other Islamic knowledge domains, such as Zakat, interest-free loans, and charitable donations.

\section{$\rightarrow$ Donations}

In fact, donations cover all the technical and administration costs, where the operator is merely a manager of the community's contributions, which implies that all the operational costs must be calculated and covered by funds.

\section{- Sadaqa}

"Sadaqa is a gift to the poor, or a virtue of Islam that can take many forms, such as a monetary gift, a physical assistance in the construction of a home, or a care for others via discussions. In fact, it is a command from God, the All-Knowing and All-Wise." Verse 6 of Sura 9.

$>$ Waqf:

According to the Muslim law, the Waqf is the immobilization of a good so that it belongs to no one but can bear fruit and benefit the poor.

\subsection{Independent Variables}

On the other hand, some performance indicators include Return on Assets (ROA) and payout ratio (ROE).

\subsubsection{Return on Assets (ROA)}

It's worth noting that the return on assets (ROA) is a measure of an Islamic bank's financial performance and management efficiency. More precisely, it shows how capable the management is at creating profits from the assets and how the assets can be managed to efficiently creates income. In fact, the average asset value is used in 
this study to determine the asset fluctuations during the year. This indicator first appeared in the financial literature as the most basic and widely used ratio for assessing banking performance (Dietrich and Wanzenried, 2011). It also assesses a bank's efficiency in generating net revenue from its assets.

$$
\text { ROE }=\text { Profit } / \text { Equity }
$$

\subsection{Control Variables: Inflation}

Inflation is defined as the drop of the purchasing power, which results in a general and prolonged rise of prices. In other words, it is a process of broad and self-sustaining price increases as opposed to some sectoral price increases that go unnoticed. To calculate the inflation rate, the consumer price index (CPI) is used.

\section{$>$ Gross Domestic Product (GDP):}

Gross domestic product (GDP) is a financial statistic that measures a country's internal economic activity as well as the value of all its products and services generated over the course of a year. This indicator is calculated as follows:

GDP $=$ sum of added value + TVA + duties and taxes on imports - Subsidies on products

\section{$>$ The size of the Islamic bank:}

For large-sized banks, developing "Islamic windows" makes it possible to set up barriers to entry, in particular to protect the "retail" market.

\section{Research Methodology}

$>$ When the RSBI is the dependent variable and the ROAA is the independent one, then, model 1 is as follows

$>$ When the RSBI is the dependent variable and the ROAA is the independent variable. Then, model 1 will be as follows.

$>$ We employed two models to assess the impact of financial performance on the RSBI, as evaluated by the ROAA and the ROAE.

$$
\text { SRIBit }=\beta 0+\beta 1 \text { ROAAit }+\beta 2 \text { INFLAIONit }+\beta 3 \text { PIBit }+\beta 4 \text { TAILLEit }+\varepsilon i t
$$

When CSR is the dependent variable and the ROAE is the independent variable, model 2 will be as follows.

$$
\text { SRIBit }=\beta 0+\beta 1 \text { ROAEit }+\beta 2 \text { INFLAIONit }+\beta 3 \text { PIBit }+\beta 4 \text { SIZEit }+\varepsilon i t
$$

\section{Results and Discussion}

To test the validity of the two models, we will proceed first with a descriptive analysis, then we will test the stationarity of the different models, and end with the specification of the models with fixed or random effects through the Haussmann test and finally, we will analyze the different regressions of both models.

The decsriptive statistics for the dependent, independent, and control variables are shown in table 2.

Table 2. The decsriptive statistics for the dependent, independent, and control variables

\begin{tabular}{cccccc}
\hline Variables & Observations & Mean & Std. Dev & Min & Max \\
\hline SRIB & 85 & 2771.904 & 11648.19 & -5.161105 & 82768.3 \\
ROA & 85 & 32.15294 & 217.6328 & -6.112 & 2013.939 \\
ROE & 85 & 1.899815 & 2.623879 & -0.704 & 13.035 \\
INFLATION & 85 & 6.613114 & 9.551404 & -8.704809 & 37.39336 \\
GDP & 85 & 91872.89 & 123688.1 & 2723.15 & 352105.9 \\
SIZE & 85 & 3.897144 & 1.156916 & 2.175946 & 6.264794 \\
\hline
\end{tabular}

It can also be seen that the mean of this dependent SRIB variable of our samples generates 2771.904. It is also said that this variable varies on average between $-5.17 \%$ and 82768.3 . It can also be seen that the mean of our sample's dependent SRIB variable is 2771.904 . This variable is also said to vary on average between -5.17 percent and 82768.3. In fact, from this table, it can be seen that the return on assets and return on capital are on average $32.16 \%$ and $1.90 \%$, respectively. Regarding the asset and equity returns, it can be noted that Islamic banks can achieve negative results of $-6.112 \%$ and $-0.704 \%$, respectively, as a percentage of assets and shareholders' equity.

Moreover, the three control variables play a more important role in this study. According to this table, inflation, the gross domestic product and the bank's size are on average 6.61 and 91872.9 and 3.90, respectively. It was 
also noted that the Islamic bank records negative results, mainly in the inflation variable, which is -8.70 but it can be seen that the value of the gross domestic product and that of the size have a positive result for the Islamic banks, which amounts at 2723.15 and 2.175946 , respectively.

Table 3. Stationarity test

\begin{tabular}{cccc}
\hline Variables & P-Value & $\operatorname{Lag}(1)$ & Results \\
\hline SRIB & 0.0949 & 0.0008 & stationary \\
ROAA & 0.0446 & - & stationary \\
ROAE & 0.0004 & - & stationary \\
Inflation & 0.0001 & - & stationary \\
GDP & 0.0918 & 0.0000 & stationary \\
SIZE & 0.0121 & - & stationary \\
\hline
\end{tabular}

For the stationarity test, we have a p-value of the ROA and the ROE lower than $0.05 \%$, which means that it is stationary, whereas the dependent variable CSR of Islamic banks and the control variable (GDP) have a p-value equal to $0.0949 \%$ and $0.0918 \%$, respectively, which is higher than $0.05 \%$, therefore, we take lag (1) to make it stationary. Moreover, after lag (1) in first difference, we notice that that the p-value becomes equal to 0.0008 and 0.0000 , i.e. less than 0.05 , which implies that it is stationary.

Table 4. The Hausman test between the two models

\begin{tabular}{lcc}
\hline & Modèle 1 & Modèle 2 \\
\hline Chi2 for Hausman test-fixed $x$ random effects & 0.87475698 & 0.88437884 \\
(Prob $>$ Chi2) & 0.9738 & 0.9961 \\
\hline
\end{tabular}

In fact, the obtained results show that we have two random effects models (p-values equal to $0.97 \%>0.1 \%$; $0.99 \%>0.1$, respectively \%, which implies that a random effects estimation method must be used. Furthermore, these findings are supported by the two models in the empirical analysis that tested the impact of social performance on the Islamic banks' financial performance, which indicates that there is a negative relationship between them. As a result, these findings are consistent with those of theoretical arguments demonstrating that current IBs' CSR activities are carried out by financial institutions.

Based on Hausmann's test, we regressed the two models that we have specified and which are different depending on the choice of the performance indicator.

Table 5. The regression of model 1 represents IBs CSR, ROA, GDP, inflation, and size

\begin{tabular}{ccccccc}
\hline SRBI & Coef. & Std. Err. & $\mathrm{t}$ value & $\mathrm{P}>|\mathrm{t}|$ & \multicolumn{2}{c}{ [95\%Conf. Interval] } \\
\hline ROAA & -571.9105 & 496.7873 & -1.15 & 0.253 & -1560.549 & 416.7278 \\
INFLATION & -2.640202 & 160.4461 & -0.02 & 0.987 & -321.9382 & 316.6578 \\
GDP & -.0173259 & .011117 & -1.56 & 0.123 & -.0394493 & .0047976 \\
SIZE & -1672.532 & 1344.112 & -1.24 & 0.217 & -4347.4 & 1002.336 \\
\hline
\end{tabular}

These findings revealed that in the Islamic banking sector, there is a substantial negative link (T-statistic=-1.15 percent) between financial performance, as assessed by the ROA, and corporate social responsibility. Moreover, the R-squared $=0.0556$ result, as well as the volatility in the ROA, explain the IBs' weaknesses in terms of CSR dependent variable and control variables. In fact, there is a substantial negative association between the control variables, such as inflation, GDP, and size (the T-statistic), which are respectively -0.02 percent, -1.56 percent, and -1.24 percent, whereas the size of Islamic banks is considerably and negatively associated to their CSR.

Furthermore, there is a significant positive relationship (with p-values of 0.987 percent, 0.123 percent, and 0.217 percent) between Islamic banks' corporate social responsibility and some control variables, such as inflation, GDP, and size (with p-values of 0.987 percent, 0.123 percent, and 0.217 percent). Similarly, the ROA has both a positive and significant $\mathrm{p}$-value (equal to 0.253 percent).

Moreover, some empirical studies support the notion of a negative relationship between CSR and financial 
performance (ROA) in Islamic banks. However, according to the opponents of CSR in Islamic banks, being socially active by engaging in charitable projects, supporting and promoting staff welfare, and minimizing environmental damage can be costly and administratively burdensome. In other words, the shari'ah's complacency with regard to other Islamic commitments is expressed in the "mission and vision dimensions" articulated around other "products and services" as a visible and daily practice therefore, their impact on financial performance is negative. On the other hand, according to Mallin et al. (2014), Belal et al. (2014), since "zakat and charity funds are considered one of the main characteristics of Islamic banks, a possible explanation for the lower disclosure of this dimension and its insignificant impact on financial performance (ROA) could be that banks show a relatively lower tendency to disclose information related to this dimension, which can be explained by Islamic ethics. This can discourage individuals and institutions from disclosing their socially responsible activities and social donations because they are considered against the dignity of those who receive them are harmful for the original intention to make a donation. Moreover, it is well known that the delivery of these social donations is mostly made in an unstructured way, which implies that in the distribution of these funds, informal donations are more frequent.

On the other hand, several researchers have empirically tested hypothesis 1, which shows a positive impact between the ROAA and CSR in the Islamic banking sector. According to Simpson, Kohers (2002) and Scholtens (2009), the results of the regression estimates in this study show the relationship between CSR and financial performance of IBs. The overall model is significant at $\mathrm{P}<0.01$ and accounts for $31.07 \%$ of the change of profitability (ROAA) in the Islamic banks of the GCC countries. In fact, the CSR disclosure variable is statistically significant at $\mathrm{P}<0.05$. Therefore, on the basis of these results, we can say that there is a positive relationship between CSR and the ROAA. As the results show, four out of five control variables are significant, notably the size, at 0.01 , the loan ratio and the capital ratio, at 0.05 and debt ratio at 0.1 , respectively, which indicates that the equation is reliable. On the other hand, the significant association between the disclosure of CSR and the ROAA is consistent with the results proved in previous studies. As a consequence, the results of the analysis, which support hypothesis 1 , are in line with those of the theoretical framework, as they predict a positive link between disclosure of the RSBI and financial performance in the Islamic banking sector. Therefore, it can be deduced that the higher the level of disclosure of high SRIB, results in a better profitability of an Islamic bank.

Table 6. Regression of model 2 represents the CRS of IBs, ROE, GDP, inflation, and size

\begin{tabular}{ccccccc}
\hline SRIB & Coef. & Std. Err & t. value & \multicolumn{1}{c}{$\mathrm{P}>|\mathrm{t}|$} & \multicolumn{2}{c}{$[95 \%$ Conf. Interval] } \\
\hline ROE & -1.27086 & 5.865178 & -0.22 & 0.829 & -12.94294 & 10.40122 \\
Inflation & 15.87821 & 160.8793 & 0.10 & 0.922 & -304.2819 & 336.0383 \\
GDP & -.0157196 & .0111138 & -1.41 & 0.161 & -.0378368 & .0063976 \\
Size & -1317.736 & 1318.676 & -1.00 & 0.321 & -3941.986 & 1306.513 \\
\hline
\end{tabular}

Moreover, these results show a significantly negative relationship between financial performance measured by the return on assets (ROA) and corporate social responsibility in the Islamic banking sector. On the other hand, the financial performance measured by the return on equity $(\mathrm{ROE})$ has a $(\mathrm{T}$-statistic $=-0.22)$ and a negative impact on the corporate social responsibility of Islamic banks. Therefore, the value of R squared of $0.0406 \%$ is weakly significant at $10 \%$ threshold, which means that the variation of the ROE is weakly explained by that of the corporate shares up to $0.0406 \%$.

On the other hand, the control variables, such as the GDP and the size (T-statistics), have a negative relationship of $-1.41 \%$ and $-1.00 \%$ ), respectively, with corporate social responsibility in Islamic banking and also a significant positive relationship with (p-value equal to $0.922 \%, 0.161 \%$ and $0.32 \%$ ). Similarly, the ROA has a positive and significant p-value with (p-value equal to $0.253 \%$ ). Therefore, this result is in line with the ones found in the first model, which show that there is a negative relationship between the financial performance and the corporate social responsibility of Islamic banks.

Finally, we conclude this study by stating that the second result shows a negative relationship between the CSR and financial performance (ROE) of the Islamic banks. Therefore, since it does not confirm the existence of a positive relationship between corporate social responsibility and financial performance in Islamic banks, hypothesis 2 is rejected.

In fact, there are several researchers who have empirically tested hypothesis 2 , which shows a positive relationship between the ROA and the CSR in the Islamic banking sector. According to Arshad et al. (2012), the 
regression carried out to test the effect of the CSR of IBs on the ROE in the Islamic banking sector is represented by the value of $\beta$, which is equal to 0.665 (then, it is positive), while the T value is 1.543 to 0.05 ). The results of this regression show that corporate social responsibility has a positive relationship with return on equity. In fact, CSR includes both donations and employees.

\section{Summary and Conclusions}

As part of our work, we are interested in this issue, which is the impact of the financial performance and corporate social responsibility of Islamic banks. To answer this question, we have divided our analysis in to two parts: a theoretical part and an empirical one.

Finally, the empirical study in this chapter is an attempt to dissect the relationship between corporate social responsibility and financial performance in the Islamic banking sector. In fact, the explanatory model of corporate social responsibility of Islamic banks has been developed based mainly on the empirical studies conducted by Hassan et al. (2010); Arshad et al. (2012); Mallin et al. (2014), Haniffa and Hudaib (2007). For this reason, we conducted tests using two models based on the approach of measuring, on the one hand, corporate social responsibility in the Islamic banks and, on the other hand, the relationship between the indicator that measures financial performance with the (ROA, ROE) and the corporate social responsibility of Islamic banks.

Furthermore, maintaining a good CSR policy would increase the ability of Islamic banks to deal with potential reputational events and negative external news they may receive in the future and therefore could protect their profits and financial results. Therefore, having a global socially responsible agenda could help Islamic banks generate a valuable goodwill that will protect them from unexpected challenges and give them access to new projects that are not available to companies with less incentives for CSR from the BIs. In fact, the "Islamic prefix" in the Islamic banking suggests an ethical identity and brand that should be supported by the Islamic finance industry rather than by diverging from such ethical behavior in the interest of greater profits. Therefore, the results of this research suggest some key policy implications. In fact, to integrate the social dimension of the Islamic moral economy into the business strategy of Islamic banks, it is important to make the objectives of social responsibility more explicit by reconsidering the approach of Islamic banks to the CSR activities of the IBs, some dimensions of which are identified in this empirical research.

\section{References}

Ahmad, K. (2000). Islamic finance and banking: challenges and prospects. Rev. Islam. Econom., 9, 57-82.

Aribi, Z. A., \& Gao, S. S. (2012). Narrative disclosure of corporate social responsibility in Islamic financial institutions. Manage. Audit. J., 27(2), 199-222. https://doi.org/10.1108/02686901211189862

Arshad, R., Othman, S., \& Othman, R. (2012). Islamic corporate social responsibility, corporate reputation and performance. World Academy of Science, Engineering and Technology, 64, 1070-107.

Aupperle, K. E., Carroll, A. B., \& Hatfield, J. D. (1985). An empirical examination of the relationship between corporate social responsibility and profitability. Academy of Management Journal, 28(2), 446-463.

Barnett, M. L., \& Salomon, R. M. (2006). Beyond dichotomy: The curvilinear relationship between social responsibility and financial performance. Strategic Management Journal, 27, 1101-1122. https://doi.org/10.1002/smj.557

Belal, A. R., Abdelsalam, O., \& Nizamee, S. (2014). Ethical reporting in Islami Bank Bangladesh Limited (1983-2010). J. Bus. Ethics. https://doi.org/10.1007/s10551-014-2133-8

Dietrich, A., \& Wanzenried, G. (2011). Determinants of bank profitability before and during the crisis: Evidence from Switzerland. Journal of International Financial Markets, Institutions and Money, 21, 307-327. https://doi.org/10.1016/j.intfin.2010.11.002

Dusuki, A. W. (2008). What Does Islam Say about Corporate Social Responsibility? Review of Islamic Economics, 12(1), 5-28.

Haniffa, R., \& Hudaib, M. (2007). Exploring the ethical identity of Islamic banks via communication in annual reports. J. Bus. Ethics, 76, 97-116. https://doi.org/10.1007/s10551-006-9272-5

Hassan, A., Harahap, S., (2010). Exploring corporate social responsibility disclosure: the case of Islamic banks. Int. J. Islam. Middle E Finance Manage., 3(3), 203-227. https://doi.org/10.1108/17538391011072417

Hopkins, M. (1999). The Planetary Bargain: Corporate Social Responsibility Comes Of Age. New York: Macmillan. https://doi.org/10.1007/978-1-349-27066-8

Jensen, M. C. (2001). Value maximization, stakeholder theory, and the corporate objective function. Journal of 
Applied Corporate Finance, 14(3), 8-2. https://doi.org/10.1111/j.1745-6622.2001.tb00434.x

Lea, R. (2002). Corporate social responsibility: IOD member opinion survey. The Institute of Directors, UK.

M.kabir Hassan et al. (2000). Ont analysé comment les caractéristiques de la banque islamique Indonesia. Review of Islamic Economics, 11(2), 17-29.

Maali, B., Casson, P., \& Napier, C. (2006). Social reporting by Islamic banks. Abacus, 42(2), 266-289. https://doi.org/10.1111/j.1467-6281.2006.00200.x

Mallin, C., Farag, H., \& Ow-Yong, K. (2014). Corporate social responsibility and financial performance in

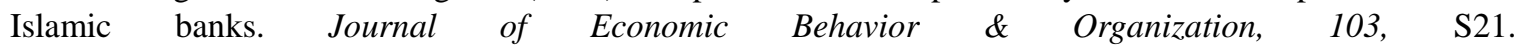
https://doi.org/10.1016/j.jebo.2014.03.001

McWilliams, A., \& Siegel, D. (2001). Corporate social responsibility and financial performance: Correlation or $\begin{array}{llll}\text { misspecification?.Strategic } \quad \text { Management } & \text { Journal, }\end{array}$ https://doi.org/10.1002/(SICI)1097-0266(200005)21:5<603::AID-SMJ101>3.0.CO;2-3

Perrini, F., Russo, A., Tencati, A., \& Vurro, C. (2011). Deconstructing the relationship between corporate social and financial performance. Journal of Business Ethics, 102(1), 59-76. https://doi.org/10.1007/s10551-011-1194-1

Preston, L. E., \& O’Bannon, D. P. (1997). The corporate social- financial performance relationship: A typology and analysis. Business Society, 36, 419-429. https://doi.org/10.1177/000765039703600406

Simpson, W. G., \& Kohers, T. (2002). The link between corporate social and financial performance: Evidence from the banking industry. Journal of Business Ethics, 35, 97-109. https://doi.org/10.1023/A:1013082525900

Soana, M. G. (2011). The relationship between corporate social performance and corporate financial performance in the banking sector. Journal of Business Ethics, 104, 133-148. https://doi.org/10.1007/s10551-011-0894-x

Waddock, S. A., \& Graves, S. B. (1997). The corporate social performance-financial performance link. $\begin{array}{llll}\text { Strategic Management } & \text { Journal, } & \text { 303-319. }\end{array}$ https://doi.org/10.1002/(SICI)1097-0266(199704)18:4<303::AID-SMJ869>3.0.CO;2-G

Zahid, P., \& Pervaiz, A. (2004). An Islamic perspective on the lack of social responsibility in business organisations. Management Research Centre, Wolverhampton University Business School, Working Paper Series .

Ziauddin, S. (2003). Islam, Postmodernism and Other Futures: A Ziauddin Sardar Reader. London: Pluto Press.

\section{Copyrights}

Copyright for this article is retained by the author(s), with first publication rights granted to the journal.

This is an open-access article distributed under the terms and conditions of the Creative Commons Attribution license (http://creativecommons.org/licenses/by/4.0/). 